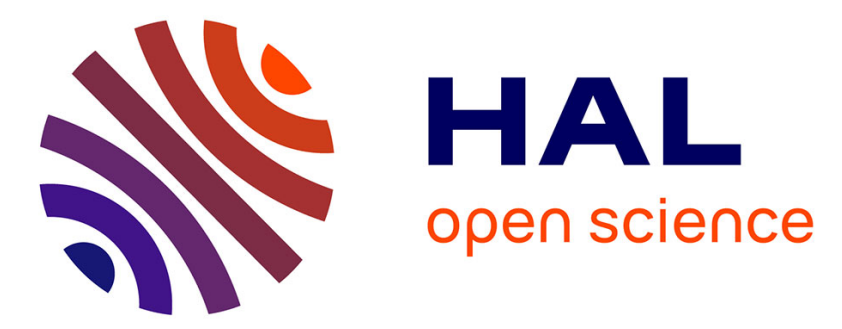

\title{
The Arcachon Bay estuary: a "collage" of landscapes
}

Frédéric Bertrand

\section{To cite this version:}

Frédéric Bertrand. The Arcachon Bay estuary : a "collage" of landscapes. Landscapes and Landforms of France, Springer Verlag, p. 71-80, 2013. hal-01067267

\section{HAL Id: hal-01067267 https://hal.science/hal-01067267}

Submitted on 24 Sep 2014

HAL is a multi-disciplinary open access archive for the deposit and dissemination of scientific research documents, whether they are published or not. The documents may come from teaching and research institutions in France or abroad, or from public or private research centers.
L'archive ouverte pluridisciplinaire HAL, est destinée au dépôt et à la diffusion de documents scientifiques de niveau recherche, publiés ou non, émanant des établissements d'enseignement et de recherche français ou étrangers, des laboratoires publics ou privés. 


\title{
The Arcachon Bay Estuary: A "Collage" of Landscapes
}

\author{
Frédéric Bertrand
}

\begin{abstract}
The Arcachon Bay is a typical semi-sheltered lagoon located on the Atlantic coast of France, facing the wave-dominated shelf of the Bay of Biscay. Its long-term evolution was controlled by the development of the Cap Ferret barrier spit and the establishment of a tide ebb-dominant barrier system leading to a spatial split of the bay in two parts: (a) the inner lagoon mostly composed of tidal flats and (b) the outer lagoon with higher hydrological capacities where a large-scale tidal inlet is bordered by the largest coastal dune in Europe. The identification of major interactive sedimentary environments with reference to their representative and complementary characteristics leads to a deductive selection of five landforms supporting oyster cultivation and various recreational (sportfishing, sailing, ecotourism) activities of both economic and landscape value.
\end{abstract}

\section{Keywords}

Biogeomorphology • Barrier system • Salt marsh • Coastal dune • Land reclamation

- Coastal management

\subsection{Introduction}

Arcachon Bay is a large $\left(174 \mathrm{~km}^{2}\right)$ mesotidal shallow lagoon located on the southwestern Atlantic coast of France $\left(44^{\circ} 40^{\prime}\right.$ $\mathrm{N}, 1^{\circ} 10^{\prime} \mathrm{W}$; Fig. 8.1) and the only major embayment along the remarkably drift-aligned coast of the Landes of Gascony. It is connected to the Atlantic Ocean by a $2-3 \mathrm{~km}$ wide and about $12 \mathrm{~km}$ long channel called "the passes du Bassin" that enables important seawater exchanges and therefore the development of an important oyster farming industry. Likewise, various recreational activities have been developed since the early creation of Arcachon seaside resort in the late 1850s - with the extension of the rail line - and early 1860s, in relation with local (Bordeaux) and foreigner (England) upper middle-class interest for sporting activities and beach pleasures. From a

F. Bertrand $(\square)$

Department of Geography, Paris-Sorbonne University, Institut de Géographie, 191, rue Saint-Jacques 75005,

Paris, France

e-mail: frdric.bertrand@gmail.com geomorphological point of view, the Arcachon area is more well known for the dunes that surround the lagoon, especially the impressive Great Dune of Pyla than for its inland low-lying and yet varied landscapes. As a matter of fact, Arcachon Bay occurs within a patchwork of interactive sedimentary environments (i.e., mainland, backbarrier, lagoon, inlet, barrier, barrier platform, and shoreface) nested at different scales, each with distinct morphology, sediment, and habitat patterns but associated in a complete and unique barrier island geosystem.

\subsection{General Setting \\ 8.2.1 Long-Term Morphological Development}

Arcachon Bay as such is one of these six interactive sedimentary environments, bounded on the seaward side by the Cap Ferret barrier spit and on the mainland side, both to east and to the south, by a very crenulated shoreline as the lagoonal water intersects small drowned river valleys (crastes) and artificial 


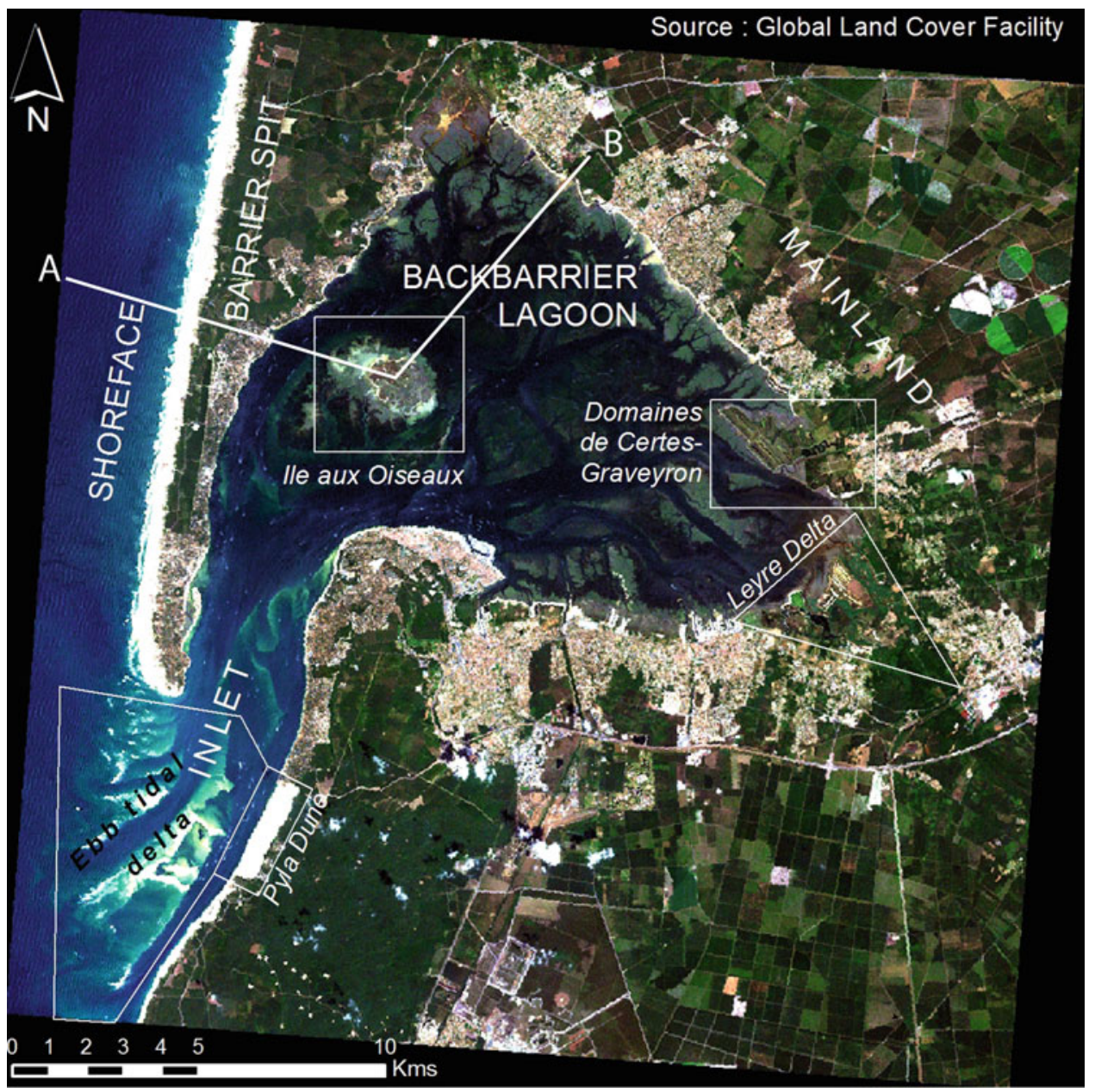

Fig. 8.1 True color composite image (R3G2B1) of Arcachon Bay showing the triangular-shaped shallow lagoon within a pine forest environment partly cultivated (cornfields), facing growing urban and recreational land-use pressures. Sedimentary environments, selected geomorphological landscapes of high value (polygons), and stratigraphic cross section (broken line, Fig. 8.2) are indicated (U.S. Geological Survey, Global Land Survey, 2001, Landsat ETM+, 30 m scene ETM+, L71200029_02920050712, USGS, Sioux Falls, South Dakota) headlands due to salt-marsh embankments for reclamation. The total barrier-lagoon system is a three-dimensional feature (Fig. 8.2) including a sequence of sediments up to $30-35 \mathrm{~m}$ thick that have developed over a time span of 14,000 years from 18,000 years B.P. to 4,000 years B.P. (Féniès and Lericolais 2005). The processes forming sand barriers lead to the development during the postglacial sea-level rise of a transgressive barrier system with the overlapping of coarse-grained sands and sandy gravels with marine shell debris - typical of tidal channel deposits - over Neogene to lower Pleistocene alluvial deposits truncated by the extensive Aeolian coversand of the Landes region $\left(13,000 \mathrm{~km}^{2}\right)$.

When the sea level reached a stillstand, around 4,000 years $\mathrm{BP}$, the Leyre estuary started being transformed into an open lagoon with a main channel oriented to the northwest according to the structural axis of the northwest-southwest trending Leyre normal fault (Faugères et al. 1986). The present-day triangular shape of the bay is a consequence of the formation of the Cap Ferret littoral spit between 2,200 years B.P. and 1,900 years B.P. in response to a wave power increase following the subboreal/ sub-Atlantic climate instability or a decrease in tide power related to the lagoon sediment infill (Allard et al. 2009). The unconsolidated, easily eroded underlying Pleistocene sands permitted an extensive $(30 \mathrm{~km})$ shift of the inlet to the south. Since that period continued sediment supply from the foreshore, stable sea level, low subsidence, and natural fixation of the primary generation of coastal dunes (Tastet and Pontee 1998) prevent the Cap Ferret spit from submerging or migrating landward. Instead, the barrier continued to migrate laterally into an open-end barrier inlet, inducing a morphodynamic response by all the elements of the barrier system (Fig. 8.3).

\subsubsection{Hydrological and Hydrodynamic Characteristics}

The most obvious characteristic of the landscape of the backbarrier lagoon is surface-area variability related to ebbing and 


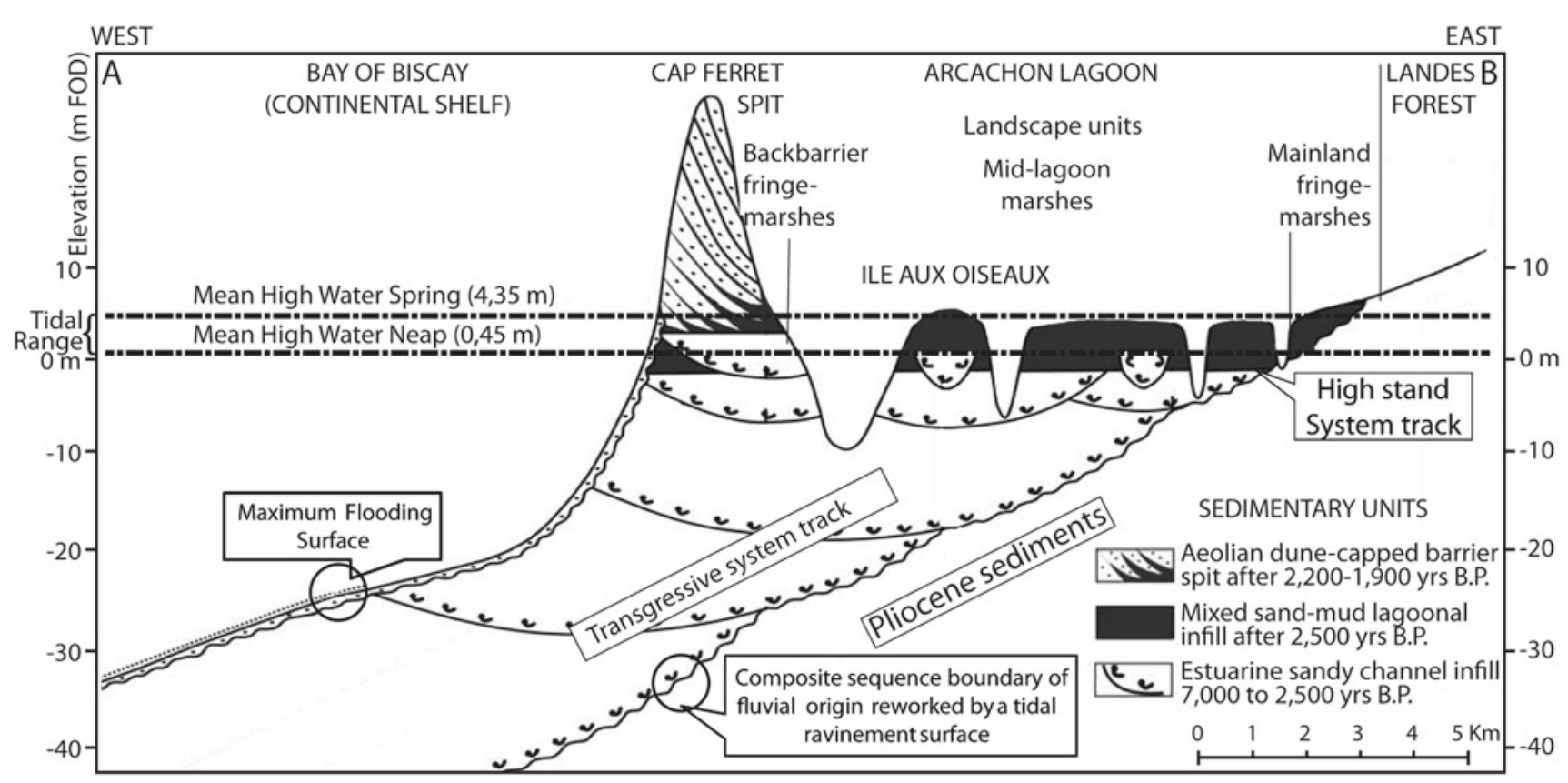

Fig. 8.2 Stratigraphic cross section revealing the Holocene internal architecture of the incised valley of the Leyre and the distribution of subenvironments in the Arcachon barrier lagoon. The cross section is located on Fig. 8.1 (Redrawn and modified with the permission of Gilles Lericolais after Fig. 8.3 in H. Feniès and G. Lericollais, 2005) flooding tides and resulting from emergence of extensive intertidal features (oyster reefs, tidal flats, bars) during low-water stages of the tide (Fig. 8.1). At millennial scale this open-water backbarrier lagoon must be related to the original pattern of the basin fill - a relatively deep engulfed shoreface - and a low rate of sediment input with respect to the basin capacity. Thus, the tidal prism (384 millions of cubic meters) is directly related to a mesotidal range (varying from 2.1 to $4.8 \mathrm{~m}$ ), and water surface area increases greater than $200 \%$ between spring low $\left(40 \mathrm{~km}^{2}\right)$ and high tides $\left(172 \mathrm{~km}^{2}\right)$. Annual freshwater inputs average $1.25 \times 10^{6} \mathrm{~m}^{3}$ with a major part (4/5) coming from the Leyre River located in the southeastern part of the bay (Plus et al. 2009). Since the tidal prism increases seaward, a funnelshaped morphology typifies all tidal flats and salt-marsh channels. As a result of an asymmetrical current pattern causing the development of flood-dominated and ebb-dominated channels, the lagoon surface exhibits an intricate network of anastomosing channels $\left(57 \mathrm{~km}^{2}\right)$ isolating large tidal flat areas $\left(117 \mathrm{~km}^{2}\right)$ made of permeable muddy sand.

In contrast, the external part of the bay is dominated by subtidal open water with a typical mixed-energy environment. Flow velocities can reach $2 \mathrm{~m} / \mathrm{s}$ southward the Cap Ferret sand spit (Cayocca 2001), whereas high energy North Atlantic of swells traveling mainly from the W-NW sector generate a strong southerly longshore drift of approximately $700,000 \mathrm{~m}^{3}$ of sediment per year (Michel and Howa 1997). Nevertheless, current profiles and waterlevel measurements recorded during the severe Joachim storm in December 2011 show that under severe wave conditions $(\mathrm{Hs}>6.0 \mathrm{~m}$ ) and despite high incidence of waves from the $\mathrm{NW}$ (nearly $10^{\circ}$ ), the longshore drift is weaker $(1<1 \mathrm{~m} / \mathrm{s})$ than under "usual" storm conditions associated to Hs =4-5 m (Sénéchal et al. 2013).

\subsection{Geomorphological Landscapes}

\subsubsection{The Ebb Tidal Delta Including the Arguin Bank}

On the seaward side of the inlet shoreline, dynamics is dependent on the configuration of a typical ebb tidal delta where strong littoral drift implies significant channel and sandbank migration (Lafon et al. 2002). Michel and Howa (1997) proposed a one- to two-channel 80-year cyclical morphological evolution under the control of external hydrodynamic forcing. When there is a single ebb channel, longshore drift on the updrift side of the inlet accumulates sediment into a spit, while sand bypassing delivers sediment to the downdrift shoreline, which is subsequently caught in littoral drift reversal and causes a progradation of the shoreline. Conversely, when the two-channel morphology becomes dominant, more sediment is trapped on the ebb delta, which leads to a deficit on the downdrift shoreline, and subsequently erosion occurs. Although the overall cyclic behavior of Arcachon tidal inlet is not yet clearly defined, it is important to acknowledge the cyclical change in ebb tidal volume that was associated during the second half of the nineteenth century with the Arguin bank migration and the consequences for the adjacent shoreline and coastal dune. 


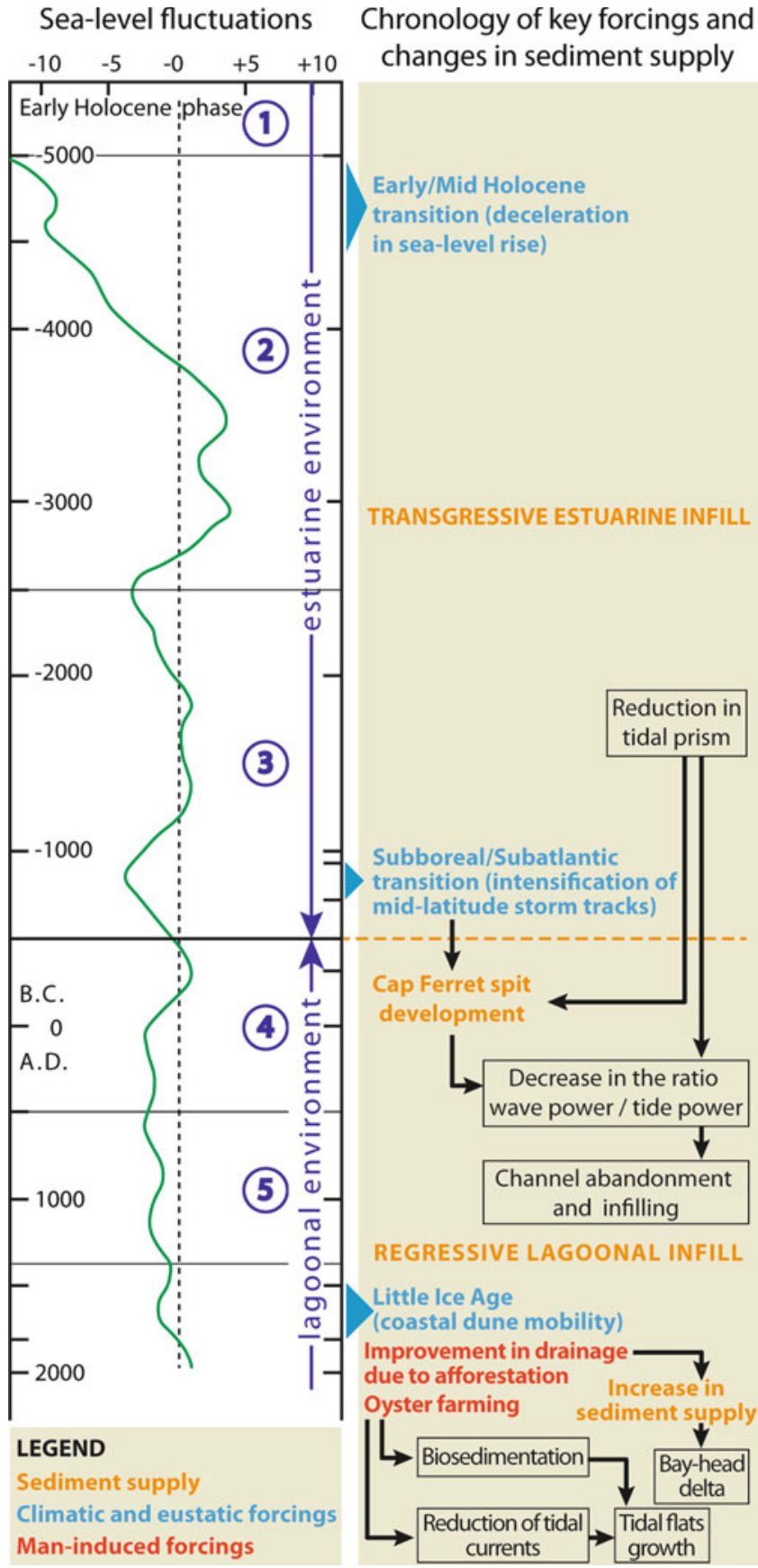

Fig. 8.3 Millenary evolution from the Leyre estuary to the Arcachon lagoon revealing the main parameters forcing their infill. The estimate ages of the five filling successive stages are indicated (After Froidefond and Legigan 1985; Féniès and Lericolais 2005; Allard 2008)

\subsubsection{The Pyla Perched Dune}

The adjacent beach south of the Arcachon tidal inlet is crowned by the highest $(108 \mathrm{~m})$ coastal dune in Europe and appears from above as a somehow unlikely simple feature of the Arcachon Bay landscape (Fig. 8.4).
Dark lines corresponding to old soils (paleosols) appear on the landward side of the dune although partly buried when crowd shuffling is greater. They make it possible to reconstruct a polyphase vertical accretion of that enormous accumulation (approximately $60 \times 10^{6} \mathrm{~m}^{3}$ ) of sand (Froidefond and Legigan 1985). From the base of the dune to summit, four main paleosols have been distinguished and dated by radiocarbon ages, palynologic analysis, and historic dating. The base of the dune is underlined by an old podzol dated at $1650 \mathrm{BC}$ and exposed by the eroding shoreline. It represents the remnant of a sandy soil covered by a large forest when the sea was $6-8 \mathrm{~km}$ further west. Paleosol 2 located between 2 and $5 \mathrm{~m}$ above sea level and paleosol 3 (Fig. 8.5) with altitude from 20 to $40 \mathrm{~m}$ correspond to the upper part of two major transgressive dunefields composed of compound parabolic dunes built by the reworking of the coversand of the Landes and fixed by the natural development of pine forest until the early 1700s. The latter undulating level dated at $1600 \mathrm{AD}$ marks a major discontinuity in dune development with an evolution of the system from parabolic to crescentic in response to climatic changes (i.e., during the "Little Ice Age"), channel migration, and large-scale management strategies. Thus, the following part of the accumulation limited by paleosol 4 represents the backslope of a crescentic dune that invaded the parabolic system and buried paleosol 3 below $50 \mathrm{~m}$ of sand reaching $80 \mathrm{~m}$ in height.

Since this dune called "Dune de la Grave" was moving very quickly, an attempt was begun to stabilize sands by planting pines. It failed because of the migration of about $500 \mathrm{~m}$ of the southern tidal channel to the foot of dune. As a consequence vegetation began to be stripped away. Part of the sands nourished the tidal banks, but another part was transported by the wind toward the summit and deposited on the young pines (paleosol 4) resulting in the present Pilat dune construction as well as on the lee side increasing eastward progression of the overall sand accumulation.

Presently Aeolian activity and dune mobility are clearly demonstrated by wind-borne accumulations around the crest of the dune as well as avalanche of sands and sand encroachment burying surrounding roads and houses. On the seaward side of the dune, the landward displacement of both the dune crest and shoreline (dune toe) can be attributed to the recent construction of a seawall in 1994 along the "Corniche road" to the Pyla beach generating diffracted but still energetic waves instead of deflecting the wave energy away from the coast (Fig. 8.5). In order to reduce sand losses in the surf zone and to prevent eastward inlet channel migration from taking more of this strongly frequented beach, sand nourishment has been reinforced since 2003 and may temporarily enlarge the Aeolian sand transport rate to the perched Pyla dune. 


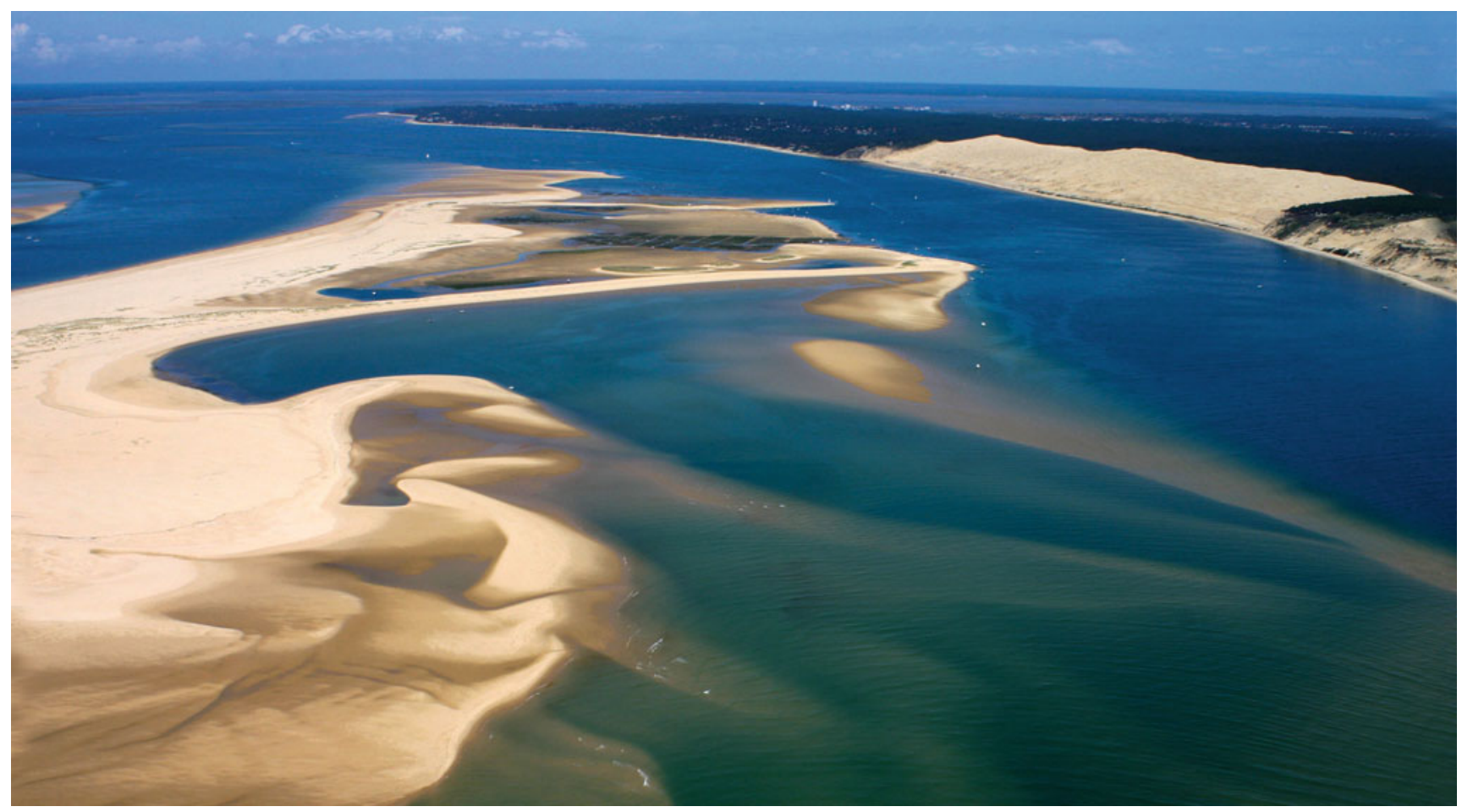

Fig. 8.4 Great Transverse dune of Pyla $(108 \mathrm{~m})$ facing the south tidal channel of Arcachon lagoon inlet and the Arguin sandbank. Oyster farms have established since the 1990s on shoals sheltered from wave action but not from surge-tide floods. Arcachon Bay in the background (With the kind permission of Michel Boudigues, publication director of three Axes Services Loisirs)

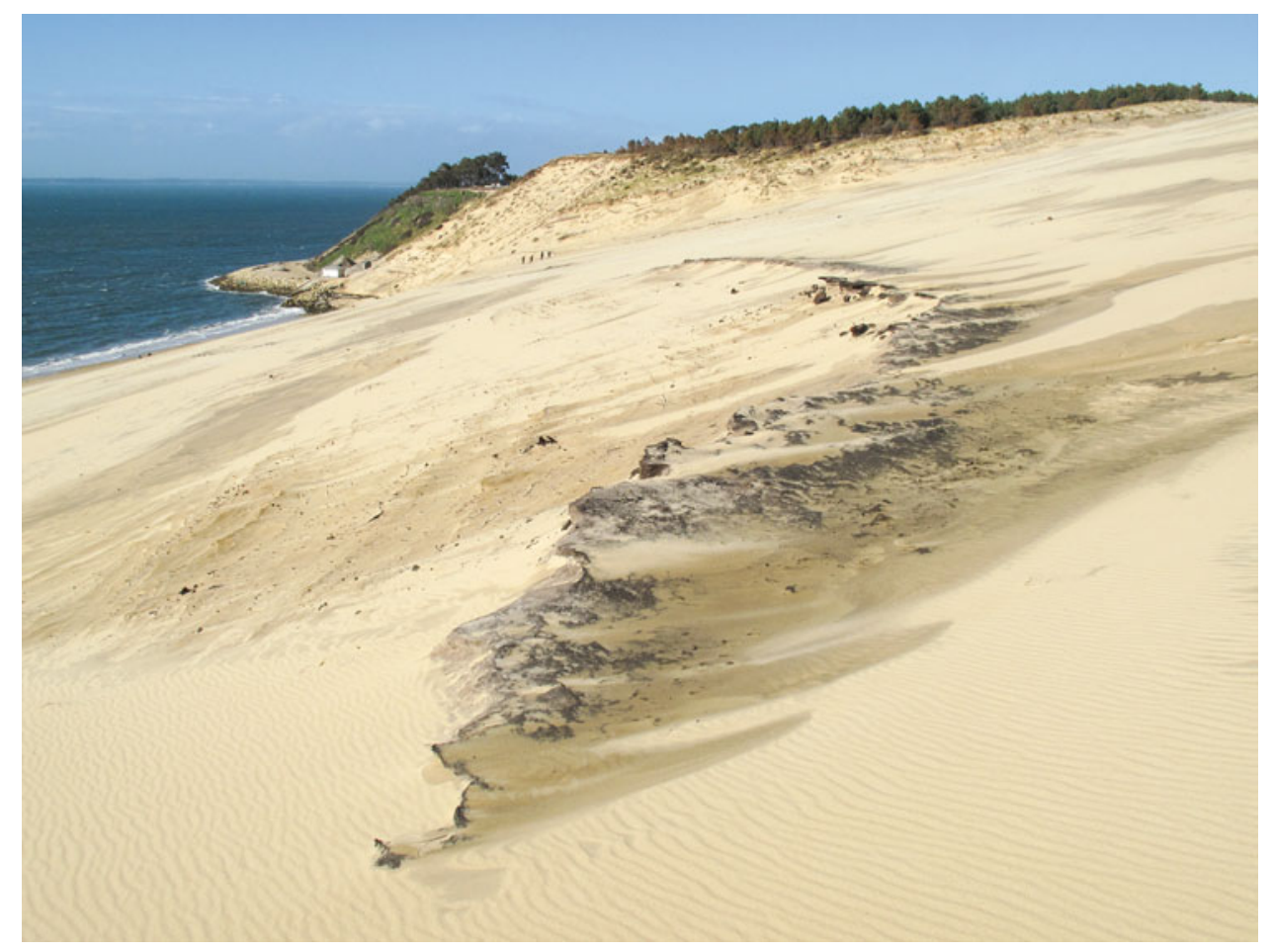

Fig. 8.5 Pyla retrograding beach and steep cliff-like scarp at the back (Photo F. Bertrand 2010). "Paleosol 3" represents the surface of the parabolic dunes fixed by the natural development of pine forest until the early 1700 s. It is overlain by the backslope of the "Dune de la Grave" that invaded the parabolic system and buried it under $50 \mathrm{~m}$ of sand. In the nineteenth century, an attempt was made to stabilize these Aeolian sands by planting a pine forest. The rocky revetment placed at the toe of the slope to protect the Corniche road has caused erosion and shoreline retreat more than $30 \mathrm{~m}$ south of the breakwater 


\subsubsection{Tidal Flats and Seagrass Meadows}

Since the lagoon surface is not heavily aggrading, the shallow floor behind Cap Ferret spit has maintained an extensive system of tidal flats mainly made of muddy sand that encloses the largest $\left(70 \mathrm{~km}^{2}\right)$ seagrass meadow of Zostera noltii in Europe (Auby and Labourg 1996).

Although not a spectacular landscape, these tidal flats are of major ecological and socioeconomic value for the Arcachon Bay since they exhibit substantial rates of both primary and secondary productivity, support diverse epiphyte and faunal communities, and are important nursery environments for many fish species. Moreover, the seagrass dense leaf canopy and root/rhizome structure provide a high potential for exporting the large anthropogenic N-inputs to the lagoon due to forest areas in the catchment being replaced by intensive maize farming - as well as reducing internal $\mathrm{N}$-loading. These morphological attributes also help to stabilize bottom sediments and trap fine particles and sediment from the water column (Ganthy et al. 2010). Thus, the changing character of the accretional surfaces that maintain elevations suitable for Zostera spp. growth is likely to play an important role in determining marsh distribution patterns and evolution within a sediment-deficit basin where suitable sites for marsh plants colonization are confined to the margins of the basin.

\subsubsection{Leyre Bayhead Delta and Marshes}

Although they represent less than $10 \%$ of the total surface area of the barrier lagoon (including reclaimed areas), the Arcachon Bay salt marshes exhibit a wide range of morphological variations and landscapes. This is due to the variety of relict antecedent surfaces that intercept the upper part of the tidal zone and to a complex history of alterations by human activities through enclosure for salt production, fish production, and agriculture as well as urban infill since the three last centuries. Two distinct geomorphic settings for marsh development can be distinguished: valleys and headlands (or interfluves) between the valleys.

The extensive Leyre valley marshes are the most distinctive marsh unit surrounded by the mainland on each coast side of the south (Leyre du Teich) and north (Leyre de Malprat) distributaries of a typical fluvial-sourced bayhead delta. The reconstruction of the chronostratigraphic framework of the Leyre incised valley shows that this original setting was made possible by progradation from about 2,500 B.P. to present day of a very thin depositional system (a few meters thick) of fluvial origin over a well-developed (30-35 m thick) retrogradational system deposited during early Holocene phase (before 7,000 B.P., unit 1) until well after the slowdown of sea-level rise. Thus, the fluvial-sourced bayhead delta of the Leyre represents the progradational system deposited after maximum transgression since the rate of creation of accommodation is less than the rate of sediment supply (Fig. 8.3).

Assuming that significant changes occurred at mouths of the river during the second half of the eighteenth century in relation with pine tree plantation, decrease in the fluvial discharge and a lesser capacity of the Leyre River to transport (Bressolier-Bousquet 1991), the upper part of the Leyre estuary filling could have occurred in a time span shorter than 250 years, mostly during that recent period of extensive land-use changes. Thus, the cross-sectional areas of distributaries are considerably smaller than the antecedent valley particularly in the south part of the delta where the fluvial influence has been reduced as a consequence of land reclamation on both insular (Malprat) and continental (Le Teich) sides of the channel and confined to a narrow, steep-sided tidal channel.

Relative important velocities (up to $100 \mathrm{~m}^{3} / \mathrm{s}$ ) and high freshwater discharge (around 658 million $\mathrm{m}^{3} / \mathrm{year}$ ) still occur in the wider north distributary. As a consequence previous halophilic vegetation (Juncus maritimus) covering this part of the deltaic plain has been gradually replaced and relegated to downstream parts of the channel by extensive common reed beds (Phragmites australis) tending to form dense impenetrable monospecific stands (Fig. 8.6).

Because these communities represent an important habitat for water birds, they are widely converted into ponds ("lacs de tonne") and managed (cutting, land forming) for hunting purpose. Although not considered as a natural habitat of community interest, it belongs to a mosaic of different wetland habitats covering a total area of 5,175 ha which was designated in February 2012 by the Ramsar Convention as a wetland site of international importance for conservation.

The left side of the southern distributary located on the municipality of Teich and formerly reclaimed during the eighteenth century from the sea to create "fish reservoirs" became a protected nature reserve in 1972. Although the Teich Bird Reserve is relatively small (120 ha), its location on the flyway paths of numerous migratory birds and carefully designed experimental manipulation of habitat that control for complexity and surface areas allow a great richness of birds (260 species) and a high number of tourists (70,000 a year).

\subsubsection{Certes and Graveyron Reclaimed Salt Marshes}

Along the mainland sides of the lagoon both to north and the west of the bayhead delta, the distribution of fringe marshes was primarily related to the high drainage density of mainland inducing the formation of extensive interfluve (or headland) marshes between the valleys that drain into the lagoon. 


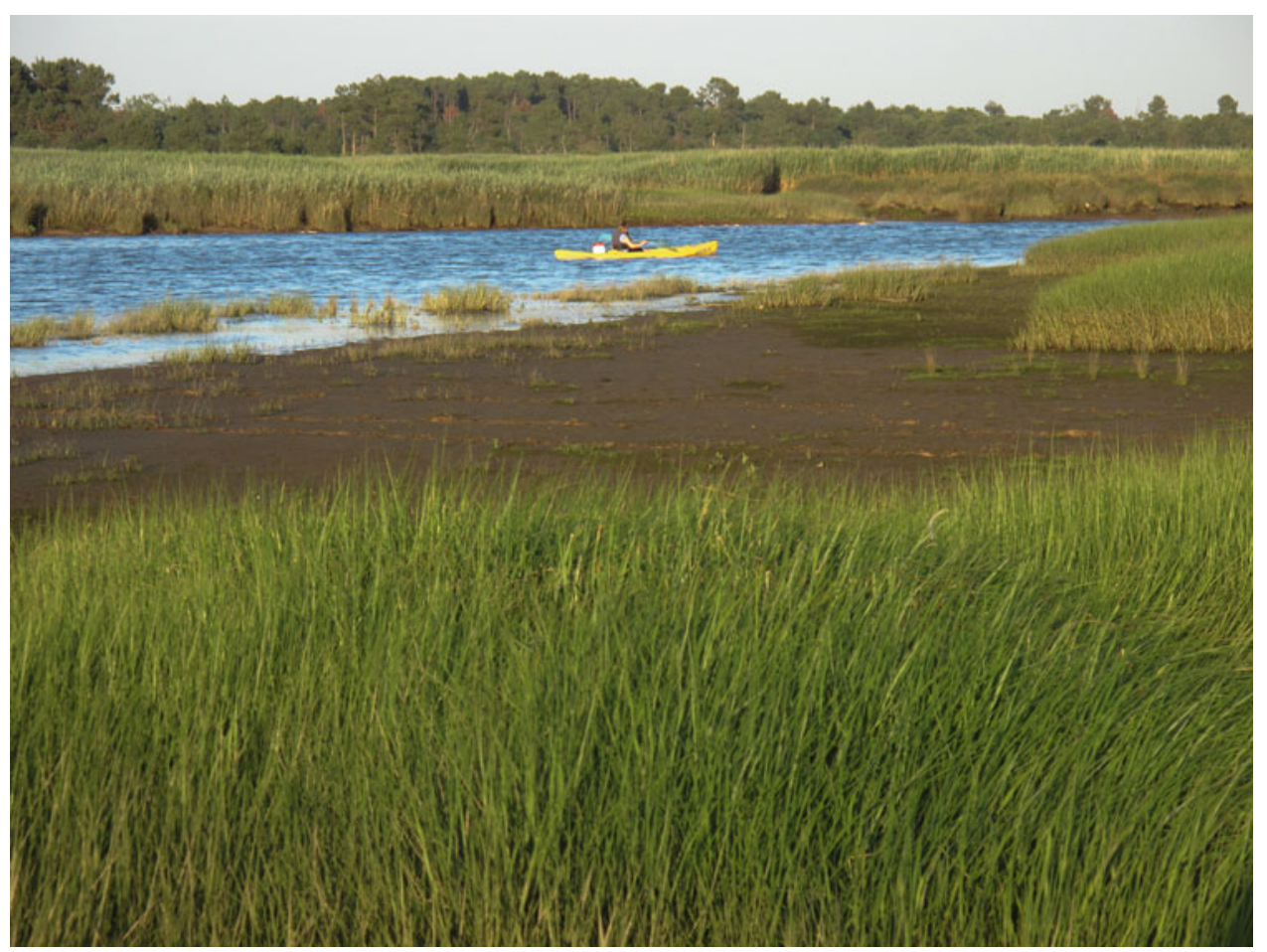

Fig. 8.6 Funnel-shape mouth of Leyre delta north distributary (Eyre de Malprat). Discontinuous fringe of Spartina maritima communities backed by Juncus maritimus and followed by the expansion of the emergent Phragmites australis (Photo F. Bertrand 2010)

However, these mainland fringe marshes have been severely deteriorated under the impact of successive embankments on their landward side, harbor structure construction on their lateral side, and erosion processes on their seaward side (Le Nindre et al. 2006). As a result, the present shoreline of the lagoon appears very irregular, even crenulated in some places where fishponds (Certes, Graveyron) and earth platforms (Gujan) were created down to the distal edge of the march isolating shore-oblique relict marshes (Lanton, Gujan).

The preservation potential of the headland marshes is variable depending on the exposure to the open water of the lagoon. In front of the reclaimed marshes forming a prominent ridge, the distal edge of the marshes often has a small step onto the adjacent tidal flats experiencing a rapid landward recession (Bertrand and Goeldner-Gianella 2010) (Fig. 8.7).

Conversely the areas behind these low-lying reclaimed marshes are protected from bay waves and have maintained extensive marshes. If ambient suspended sediment concentrations are sufficient to trap substantial quantities of settling silts as in Lanton Bay, vertical accretion and salt-marsh progradation over the shallow adjacent tidal flats may occur forming dense patches and Spartina meadows. Considering that potential tidal marsh retreat along the mainland fringes of the Arcachon lagoon is presently limited by developed features and embankments, these remaining headland marshes represent a geomorphological landscape of high value which should provide protection measures for their preservation.
Meanwhile, the idea of using de-embankment to recreate salt marshes is under evaluation from evidence of spontaneous salt-marsh formation after recent accidental dike breaching of Graveyron and Malprat polders due to storm tides (Bertrand and Goeldner-Gianella 2010) (Fig. 8.8). This alternative considered here is to give up some of the created land to the sea by realigning the coast to an existing setback dike and to promote salt accretion in the former polder so that salt marshes can provide protection of the hinterland from waves and storms. This soft coastal defense technique aims to provide a long-term solution for reducing flood risk that has increased significantly along the mainland shore of Arcachon Bay owing to the acceleration of sea-level rise (0.35 mm/year over the period 1967-2010), the increase of storm intensity and extreme surges (within the lagoon), and, last but not least, the urbanization in low-lying areas.

\subsubsection{Ile aux Oiseaux Mid-lagoon Marshes}

Ile aux Oiseaux $\left(2.7 \mathrm{~km}^{2}\right)$ is an isolated and yet most emblematic feature of the Arcachon lagoon landscapes (Fig. 8.9). Its origin is still not clearly elucidated. Assuming that the lagoon formed by the enclosure of an estuarine embayment by virtue of a migrating spit, the Ile aux Oiseaux could involve the stranding of either a former flood delta behind Cap Ferret migrating barrier spit or a beach ridge. 


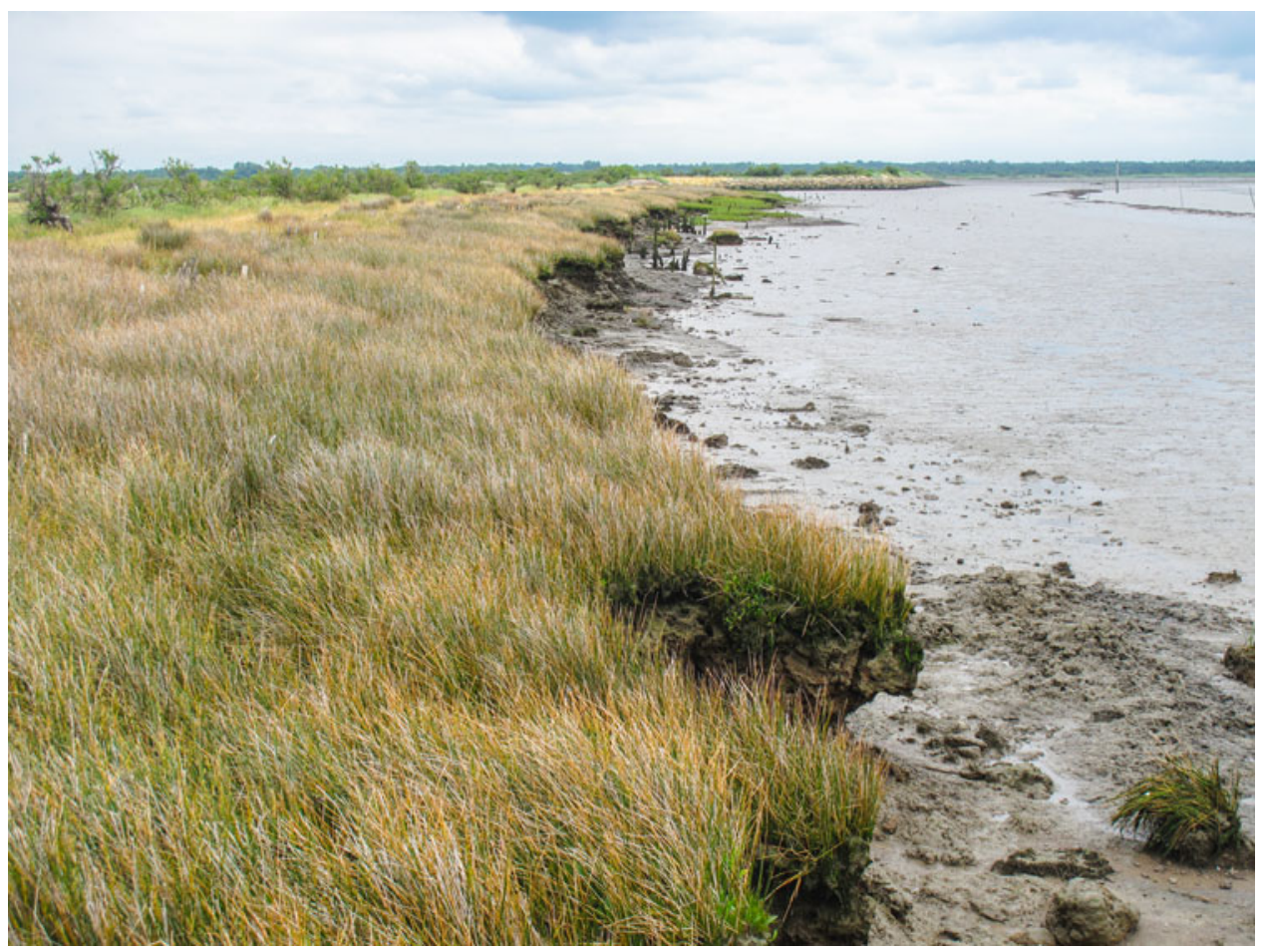

Fig. 8.7 Recession of low cliff at the transition between salt marsh dominated by Juncus maritimus communities and tidal flat in front of Graveyron polder. Erosion linked to changes in a larger-scale estuary process regime shaped by a combination of external sea-level rise, internal wind-wave forcing, and dredging of the Audenge channel (right background) (Photo F. Bertrand, 2010)

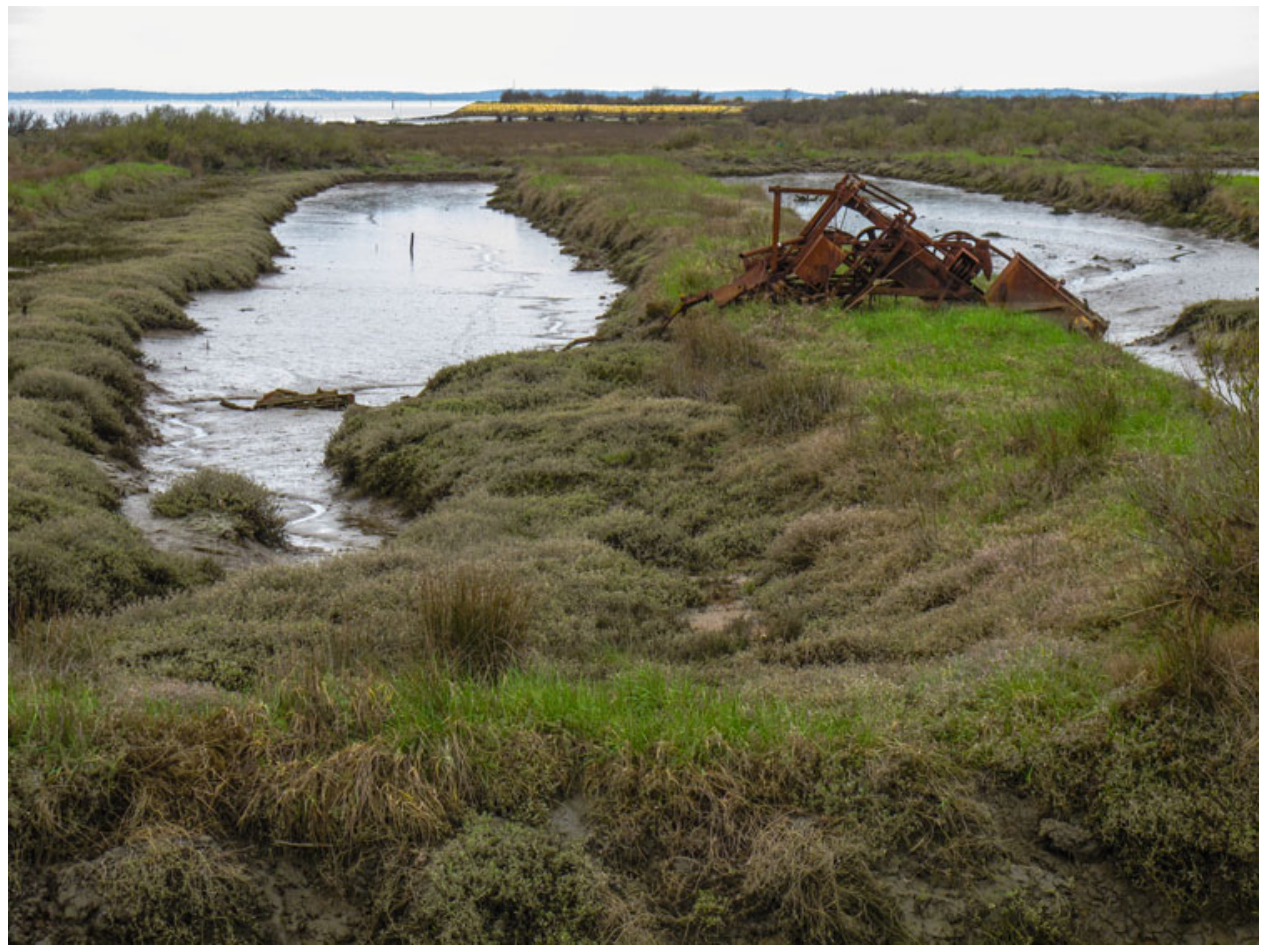

Fig. 8.8 Re-establishment of lower and middle marsh plant communities dominated by the perennial Puccinellia maritima and Halimione portulacoides within parts of the Graveyron abandoned reclamation.
The headland of Certes reclaimed salt marsh (background) is still enclosed and "hardly" protected to permit fish farming development (Photo F. Bertrand, July 2010) 


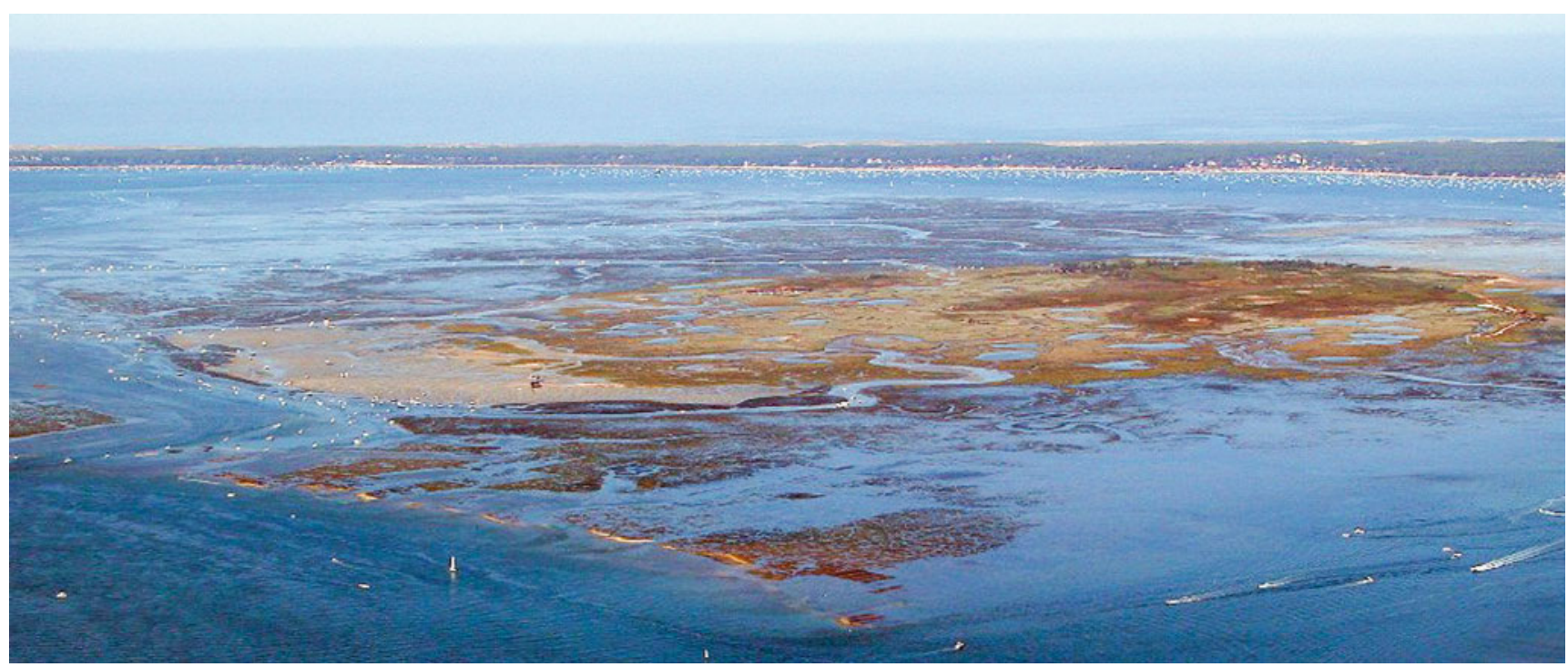

Fig. 8.9 Ile aux Oiseaux viewed from the east. Both south side (left foreground) and east side (right foreground) of the island are sheltered from the prevailing wind wave so that sediment movement is substantially lower than on the west side (background). It results in the accumulation of fine-grained sediment (muddy sand), the development of salt-marsh vegetation (green), and the relative stability of the island's shoreline. Nevertheless, the eastern part of the tidal flat or crassat assumes a strong tendency of retrogradation toward the west in connection with the widening of Mapouchet tidal channel where the highest velocities of the ebb tide occur (Photo courtesy of Philippe Dufour)
The identification around the island of the same underlying sediment facies (see above) than the Leyre valley fill (Féniès and Lericolais 2005) may confirm the abandon of such backbarrier features that have enhanced thereby the segregation of flow into ebb- and flood-dominated channels. Whatever the origin and precise nature of the Ile aux Oiseaux, the occurrence of marshes in the central section of Arcachon Bay must be determined by the changing character of a relict antecedent platform marsh into an accretional surface maintaining suitable elevations for marsh growth in relation with extensive tidal scour and fill processes near southwesterly highly dynamic part of the lagoon. Locally oyster reefs and oyster farm structures representing artificial obstacles may induce a decrease of the wave erosion and a deposition trend in the downstream part of some parks with regard to southwest wave propagation (Allard et al. 2009).

Although marsh surfaces and terrestrial habitats are relatively obvious subaerial geomorphological features, major parts of the island are subaqueous. Because the Ile aux Oiseaux has become a major destination for recreational boating and marine recreation, especially during the summer, subtidal seagrass communities are increasingly threatened by physical disturbance, e.g., sediment resuspension from propeller wash and anchor chain scour. This potential impact associated with the release of contaminants has led to the establishment of mooring regulations around the island in order to maintain some essential services provided by seagrass ecosystem including wave protection. Indeed, although considered as non-submersible, the upper part of the Ile aux Oiseaux has experienced severe flooding, i.e., far beyond the littoral zone, after the storm Xynthia hit the French coast on the 28th of February 2010. Thus, the preservation potential of these mid-lagoon marshes appears to be closely dependent on the degree to which sediment transfer and morphologic change will be able to offset submergence in this highly dynamic and heavily frequented part of the lagoon.

\subsection{Conclusions}

Considering the low-relief topography of Gascogny Lands which makes it difficult to have an overall view over the barrier island system and the increasing fragmentation of its landscapes in the last three centuries, the Arcachon Bay appears as one of the most unlikely "collage" of coastal landforms. However, the stratigraphic relationships of the various elements of the barrier system make it possible for a paleogeographic reconstruction of this outstanding and somehow unique combination of natural processes and land use along the French Atlantic coast. The description of these relations may be a valuable tool for popularization processes targeting the conservation of the lagoonal landscapes and the sustainable use of maritime public domain.

Acknowledgments The author thanks the University of Maryland (http://glcf.umiacs.umd.edu/data/glopem) for providing the Landsat $\mathrm{ETM}+$ data for analysis. 


\section{References}

Allard J (2008) Enregistrements des changements environnementaux dans les sédiments littoraux: cas des Pertuis Charentais et du Bassin d'Arcachon. Ph.D. thesis, University of La Rochelle, 277 p

Allard J, Chaumillon E, Féniès H (2009) A synthesis of morphological evolutions and Holocene stratigraphy of a wave-dominated estuary: the Arcachon lagoon. SW France Cont Shelf Res 29(8):957-969

Auby I, Labourg PJ (1996) Seasonal dynamics of Zostera noltii Hornem in the Bay of Arcachon (France). J Sea Res 35(4):269-277

Bertrand F, Goeldner-Gianella L (2010) La vulnérabilité du littoral du bassin d'Arcachon à la submersion marine: le programme BARCASUB. In: Proceedings of the Journées «Impacts du changement climatique sur les risques côtiers », BRGM, Orléans, 15 et 16 Nov. 2010, pp 203-207

Bressolier-Bousquet C (1991) Geomorphological effects of land reclamation in the eighteen century at the mouth of the Leyre river, Arcachon Bay France. J Coast Res 7(1):113-126

Faugères JC, Cuignon R, Féniès H, Gayet J (1986) Caractères et facteurs d'un comblement littoral à l'Holocène Supérieur: passage d'un domaine estuarien à un domaine lagunaire (Bassin d' Arcachon, France). Bulletin de l'Institut de Géologie du Bassin d'Aquitaine 39:95-116

Féniès H, Lericolais G (2005) Internal architecture of an incised valley-fill on a wave- and tide-dominated coast (the Leyre incised valley, Bay of Biscay, France) Comptes Rendus. Geosciences 337(14):1257-1266
Florence C (2001) Long-term morphological modeling of a tidal inlet: the Arcachon Basin, France. Coast Eng 42(2):115-142

Froidefond JM, Legigan P (1985) La grande dune du Pilat et la progression des dunes sur le littoral aquitain. Bulletin de l'Institut de Géologie du Bassin d'Aquitaine 38:11

Ganthy F, Sottolochio A and Verney R (2010) Dynamique sédimentaire d'un estran lagunaire colonisé par un herbier de zostères (Bassin d'Arcachon, France) XIèmes Journées Nationales Génie Côtier Génie Civil Les Sables d'Olonne, 22-25 juin 2010, pp 251-262

Lafon V, Froidefond JM, Lahet F, Castaing P (2002) SPOT shallow water bathymetry of a moderately turbid tidal inlet based on field measurements. Remote Sens Environ 81:136-148

Le Nindre YM, Bodéré G, Izac JL, Putot E, Levasseur J (2006) Etude pour le maintien de l'équilibre biosédimentaire des estrans de la côte sud du Bassin d'Arcachon. Rapport BRGM/RP 54814-FR. $129 p+4$ annexes

Michel D, Howa HL (1997) Morphodynamic behaviour of a tidal inlet system in a mixed- energy enviroment. Phys Chem Earth 22:339-343

Plus M, Dumas F, Stanisière JY, Maurer D (2009) Hydrodynamic characterization of the Arcachon Bay, using model-derived descriptors. Cont Shelf Res 29(8):1008-1013

Sénéchal N, Sottolichio A, Bertrand F, Goeldner-Gianella L, Garlan T (2013) Observations of waves' impact on currents in a mixedenergy tidal inlet: Arcachon on the southern French Atlantic coast. J Coast Res SI 65:2053-2057

Tastet JP, Pontee N (1998) Morpho-chronology of coastal dunes in Medoc. A new interpretation of Holocene dunes in Southwestern France. Geomorphology 25:93-109 